\title{
Kemampuan Koneksi Matematis Siswa SMA Berdasarkan Kecemasan Matematika
}

\author{
Juwita Astuti ${ }^{1}$, Caswita ${ }^{2}$ \\ ${ }^{1,2}$ Magister Pendidikan Matematika, Universitas Lampung \\ Penulis korespondensi: juwitaastuti84@gmail.com
}

\begin{abstract}
One of mathematical abilities which is concepted by NTCM must be mastered by a student is mathematical connections. Some Study's results showed that mathematics anxiety can influence students' mathematical abilities, including mathematical connections abilities. The study intends to know about mathematical connection's ability that will be reviewed from high school students,s mathematics anxiety in solving problem related to material sequences and series. The samples in this study were 36 students of class XI IPA 2 at SMA N 1 Sekampung in East Lampung in academic year 2020/2021. Qualitative approach with descriptive method is used in this study. The tehnicque in collecting the data in this study by providing students math anxiety quessionair and tests to see the abilities of mathematical connections. There were 8 students indicated high math anxiety, 19 students indicated moderate math anxiety and 9 students indicated low math anxiety. The analysiswas focused on the students who are chosen as the subject from each category. The conclusion is that studentindicated high mathematics anxiety was able to achieve the ability to connect mathematical topics, connect mathematical topics to other sciences, while students with moderate and low mathematics anxiety can only achieve mathematics connection ability in indicator of connection in and between mathematical concepts. There is an anomaly in this study, which is due to high mathematics anxiety student get mathematical connection ability tend to be better.
\end{abstract}

Keywords : Mathematical connection, mathematics anxiety, sequence

\begin{abstract}
Abstrak: Diantara kemampuan yang dirumuskan NTCM agar dimiliki oleh siswa adalah kemampuan koneksi matematis. Beberapa hasil studi menunjukkan bahwa kecemasan matematika dapat mempengaruhi kemampuan matematika siswa termasuk kemampuan koneksi matematis. Studi ini bermaksud mengetahui tentang kemampuan koneksi matematis ditinjau berdasarkan kecemasan matematika siswa dilihat dari penyelesaian soal-soal yang berhubungan dengan materi barisan dan deret. Sampel yang digunakan sebanyak 36 siswa kelas XI IPA 2 SMA N 1 Sekampung Kabupaten Lampung Timur tahun pelajaran 2020/2021. Pendekatan kualitatif dengan metode deskriptif digunakan dalam penelitian ini. Teknik dalam pengumpulan data dengan memberikan angket kecemasan matematika dan pemberian soal tes yang mengukur kemampuan koneksi matematis yaitu sebanyak 3 soal. Didapatkan 8 siswa terindikasi tingkat kecemasan matematika tinggi, 19 siswa terindikasi tingkat kecemasan matematika sedang dan 9 siswa terindikasi tingkat kecemasan matematika rendah. Analisis dilakukan terhadap 3 subjek yang mewakili setiap kategori tingkat kecemasan. Simpulan yang diperoleh adalah bahwa siswa yang terindikasi kecemasan matematika tinggi (KMT) memiliki kemampuan koneksi dalam topik dan antar topik matematika juga koneksi topik matematika dan ilmu lain, sementara siswa terindikasi kecemasan matematika sedang (KMS) dan kecemasan matematika rendah (KMR) hanya memiliki kemampuan koneksi dalam topik dan antar topik matematika. Terjadi suatu anomali dalam penelitian ini dimana subjek dengan tingkat kecemasan matematika yang tinggi menunjukkan kemampuan dalam koneksi matematis yang cenderung lebih baik.
\end{abstract}

Kata-kata Kunci: koneksi matematis, kecemasan matematika, barisan dan deret

\section{PENDAHULUAN}

Pelajaran tentang logika, mengenai susunan dan bentuk, mempelajari tentang besaran, dan konsep-konsep yang saling berhubungan satu dengan lainnya dalam mempelajari matematika. Pembelajaranmatematikadisusun berdasarkan konsep-konsep secara berurutan, 
logis, terstruktur, dan sistematis yang dimulai dari konsep yang mudah atau sederhana hingga pada konsep yang paling rumit atau kompleks (Noer, 2017). Ilmu matematika menjadi sumber perkembangan teknologi dan ilmu pengetahuan lainnya, dengan hal ini kemajuan ilmu pengetahuan sangat erat kaitannya dengan matematika(Das \& Das, 2013). Hal tersebut memaknai bahwa matematika memberikan kontribusi yang sangat besar dalam peradaban manusia sebagai perkembangan ilmu pengetahuan untuk mengembangkan kemampuan.

Kemampuan dalam pembelajaran matematika yang termasuk dari bagian standar proses adalah kemampuan komunikasi, representasi, pemecahan masalah, kemampuan penalaran dan pembuktian serta koneksi matematis. Diperjelas pula kemampuan koneksi matematis adalah kemampuan yang menggambarkanpemahaman siswamengenai topik matematika dalam matematika itu sendiri, topik dalam matematika yang berhubungan dengan topik ilmu bidang lain jugakonsep matematika jika dihubungkan dengan masalah kontekstual atau kehidupan sehari-hari. Perlunya kemampuan siswa dalam mengkoneksikan secara matematis agar siswa mampu mengidentifikasi dan menggunakan hubungan antara konsep-konsep dalam matematika, sehingga siswa memahami bagaimana konsep-konsepitu saling berkaitan dan bertumpu satu sama lain sehingga menghasilkan suatu koherensi (keterpaduan) serta agar siswa mampu mengenal dan menggunakan konsep matematika didalam maupun diluar konteks matematika itu sendiri (NCTM, 2000). Siswa yang memiliki kemampuan koneksi matematis diharapkan mampu menyelesaikan masalah Matematika dan pengaplikasian matematika pada masalah kontekstual atau masalah kehidupan sehari-hari (Putri \& Abadi, 2014). Siswa mampu menghubungkan konsep atau topik dalam matematika, mereka bisa memiliki pemahaman matematika yang lebih dalam dan bertahan lama (NTCM, 2000). Hal ini menunjukkan bahwa tujuan mata pelajaran matematika di sekolah akan dapat dicapai siswa. Salah satunya dengan penguasaan kemampuan koneksi matematis yang baik.

Pengembangan konsep matematika tidak lepas dari bagaimana matematika diajarkan pada lembaga pendidikan yang merupakan pondasi kuat dalam pengembangan matematika di suatu sekolah. Hudoyo (Nawangsari, 2001) berpendapat pemfokusan pelajaran matematika disebabkan matematika merupakan dasar untuk mengembangkan ilmu, sehingga mutlak diperlukan tenaga yang terampil dan pandai dalam matematika. Bila perkembangan ilmu matematika dapat berjalan sesuai dengan yang diharapkan maka diperoleh generasi yang berkualitas di masa yang akan datang. Namun usaha tidak selalu sama dengan yang diharapkan. Terkadang hambatan tersebut muncul baik dari dalam diri peserta didik maupun dari lingkungan sekitar atau bahkan dari matematika itu sendiri karena sudah tidak dapat disangkal lagi bahwa matematika bukan ilmu yang mudah untuk dipelajari.Salah satu hambatan yang terjadi saat ini adalah kecemasan matematika. Kecemasan merupakan suatu perasaan tidak nyaman yang sering terjadi di dalam kehidupan sehari-hari manusia.

Kecemasan adalah perwujudan dari sejumlah proses emosional ketika seseorang sedang mengalamai perasaan tertekan dan konflik atau pertentangan secara batin (Derajat, 1988 dalam Andrian, 2017). Selain itu, kecemasan adalah suatu keadaan tidak nyaman yang dirasakan meliputi ketakutan,ketegangan, kekhawatiran, perasaan bingung, tidak menyukai sesuatu secara subjektif yang muncul dari perasaan tidak aman akan bahaya yang mungkin akan terjadi (Saputra, 2014). Kecemasan matematika adalah perasaan yang menunjukkan ketidaknyamanan atau kegugupan yang dialami seseorang yang membuat kemampuan manipulative terhadap angka dan pemecahan masalah matematika yang lebih luas, menjadi terganggu baik saat belajar matematika maupun penggunaannya dalam kehidupan sehari hari (Das \& Das, 2013). Kecemasan matematika atau perasaan takut tentang matematikadari lingkungan pendidikan 
yang akrab dengan kepanikan buta ketika dihadapkan pada masalah matematika yang tidak dapat kita pahami, tetapi kecemasan matematika tidak selalu dikenali atau dipahami (Brian, 2013). Kecemasan matematika adalah ketegangan yang dapat mengganggu dalammemanipulasi dan memahami tentang bagaimana bekerja dengan angka yang dapat menyebabkan sikap negatif terhadap matematika, menghindari pemikiran matematis, pilihan karir terbatas, kurangnya kepercayaan diri, dan ketakutan akan konten (Ashcraft, 2002).Sedangkan Jackson dan Leffingwell (Istikomah \& Wahyuni, 2018) menyatakan bahwa kecemasan matematika diidentifikasi sebagai kondisi kompleks yang disebabkan oleh berbagaifaktor, terutama berkembang selama masa kanak-kanak melalui pengalaman di sekolah dasar.Dengan demikian, kecemasan matematika adalah bentuk perasaan seseorang berupa ketakutan, ketegangan atau kecemasan dalam menghadapi permasalahan matematika atau dalam kegiatan pembelajaran matematika yang ditunjukkan dengan berbagai gejala.

Kecemasan matematikadapat dikenali dari 4 aspekyaitu pemahaman/pengetahuan matematis, somatik, pengetahuan dan sikap.Aspek pemahaman matematis berhubungan dengan pengetahuan terhadap konsep matematika, diantaranya munculnya pikiran pada seseorang bahwa dia tidak cukup menguasai materi matematika. Aspek Somatic bisa dikenali dengan adanya perubahan yang terjadi pada fisik/tubuh seseorang, seperti munculnya perasaan tegang, sakit perut, keluar keringat, gemetar atau debaran jantung lebih cepat. Aspek pengetahuan bisa dikenali dari perubahan pada kognitifsaat seseorang menghadapi matematika, misalnya ketidakmampuan berfikir jernih atau lupa akan konsep konsep yang biasanya diketahui. Pada aspek sikap misalnya munculnya rasa kurang percaya diri dalam melakukan hal yang berhubungan dengan matematika (Cooke et al., 2011).

Kecemasan matematika adalah tidak dipandang sebagai suatu yang sepele, karena akibat dari ketidakmampuan siswa dalam beradaptasi pada pelajaran matematika akan menyebabkan siswa mengalami kesulitan atau fobia terhadap pelajaran matematika yang pada akhirnya bisa menyebabkan rendahnya hasil belajar siswa dan hasil penelitian yang dilakukan menunjukkan bahwa ada pengaruh negatif antara kecemasan matematika dan kemampuan koneksi matematis siswa (Anita, 2014). Selain itu, hasil penelitian lain adanya hubungan negatif juga antara kecemasan dengan kemampuan koneksi matematis yang dilihat dari persamaan garis regresi yang menurun (Fani \& Effendi, 2021). Hubungan negative antara kecemasan matematika dan prestasi matematika siswa dengan kecemasan matematika yang tinggi akan menunjukkan kinerja matematika yang buruk dan sebaliknya (Puteh\&Khalin,2016).Sedangkan,Siswa dengan kecemasan matematika pada tingkat yang tinggi mendapatkan prestasi belajar yang rendah (Zakaria \& Nordin, 2008).

Hasil observasi langsung peneliti sebagai guru matematika di SMA N 1 Sekampung bahwa sering menemukan kesulitan siswa dalam memecahkan soal matematika terutama pada bagian yang memerlukan konsep konsep matematika yang telah dipelajari. Analisis peneliti lainnya bahwa siswa cenderung mengalami kebingungan dalam menghubungkan konsep-konsep matematika yang telah didapatkan sebelumnya dengan konsep pada materi baru. Pengamatan selama proses belajar siswa juga sering mengalami kesulitan pada penyelesaian soal soal yang sifatnya kontekstual dimana letak kelemahannya adalah dalam menghubungkan masalah kontekstual dengan konsep matematika. Selain itu, siswa juga memiliki motivasi yang rendah dalam belajar matematika dan menunjukkan sikap yang cenderung pasif, tidak merespon pertanyaan guru karena khawatir jawabannya salah yang berakibat kepada rendahnya hasil belajar siswa pada materi barisan dan deret dimana hanya 55,6\% siswa mencapai kriteria ketuntasan minimal dengan rata-rata nilai 58,3 hal ini tidak mencapai target minimal ketuntasan 
klasikal sebanyak 75\% dari jumlah siswa. Alasan dipilih materi tersebut selain rendahnya hasil belajar siswa di kelas XI materi tersebut berkaiatan dengan masalah kontekstual.Berdasarkan pendahuluan dan masalah yang terjadi di SMA N 1 Sekampung maka tujuan penelitian ini adalah melihat kemampuan koneksi Matematis siswa SMA N 1 Sekampung berdasarkan kecemasan Matematika pada materi pembelajaran barisan dan deret.

\section{METODE}

Metode peneitian yang digunakan adalah kualitatif deskriptif yang dilakukan pada kondisi alamiah dan pengumpulan data berupa kata kata, gambar dan bukan angka angka. Data yang terkumpul dianalisis secara kualitatif (Sugiyono, 2019). Data yang telah didapatkan menjadi sumber utama untuk penelitian (Moelong, 2017). Sampel penelitian sebanyak 36 siswa kelas XI IPA 2 di SMA N 1 Sekampung Tahun Pelajaran 2020/2021.Instrumen yang digunakan adalah tes dan angket.

Tes digunakan mengukur kemampuan koneksi matematis siswa. Jumlah soal yang diberikan sebanyak 3 soaldengan indikator masing masing yaitu soal nomor 1 mengukur identifikasi topik dan antar topik matematika, soal nomor 2 mengukur kemampuan koneksi matematis antara topik matematika dengan ilmu lain, dan soal nomor 3 mengukur kemampuan koneksi matematis antara topic matematika dengan kehidupan sehari hari. Sedangkan, angket yang digunakan mengukur tingkat kecemasan matematika siswa didapatkan dengan mengadaptasi konsep kecemasan matematika dengan skala kecemasanmengacu pada skala Likert yang dilakukan dengan memberi tanda centang pada salah satu pilihan jawaban yang diberikan (Cooke et al., 2011).Pemberian skor pada setiap pilihan jawaban menggunakan pedoman skala Likert dengan empat opsi jawaban yaitu "sangat sering", "sering", "jarang”, dan "tidak pernah". Tahap Selanjutnya adalah mengelompokkan persentase skor jawaban siswa ke dalam tingkat kecemasan matematika dengan kategori tinggi, sedang, dan rendah. Menurut Arikunto (Fani \& Effendi, 2021) bahwa kategori kecemasan matematika ini di konversi dengan menggunakan konversi skor. Kategorisasi konversi skor kecemasan belajar siswa disajikan pada tabel 1:

Tabel 1. Kategorisasi Kecemasan Belajar Siswa

\begin{tabular}{cc}
\hline Kategori & \multicolumn{1}{c}{ Kriteria Nilai } \\
\hline Tinggi & $N>(\bar{X}+s)$ \\
Sedang & $(\bar{X}-s) \leq N \leq(\bar{X}+s)$ \\
Rendah & $N<(\bar{X}+s)$ \\
& \\
& \multicolumn{1}{c}{ Keterangan: } \\
& $N=$ skor siswa \\
& $\bar{X}=$ skor rata rata \\
& $s=$ standar deviasi
\end{tabular}

Tabel 1 di atas memberikan asumsi bahwa siswa dikategorikan memiliki tingkat kecemasan tinggi jika siswa memperoleh skor lebih dari skor rata-rata yang ditambahkan dengan standar deviasi. Siswa dikategorikan memiliki tingkat kecemasan rendah jika siswa memperoleh skor kurang dari selisih dari nilai rata-rata dengan standar deviasi. Sedangkan 
siswa dikategorikan memiliki tingkat kecemasan sedang jika memperoleh nilai yang ada diantara nilai dikategori tinggi dan rendah.

\section{HASIL DAN PEMBAHASAN}

Hasil analisis angket kecemasan matematika siswa kelas XI IPA 2 di SMA N 1 Sekampung Tahun Pelajaran 2020/2021 diperoleh persentasekategori kecemasan Matematika siswa disajikan pada Tabel 2 sebagai berikut.

Tabel 2. Hasil Analisis Kategorisasi Kecemasan Belajar Siswa

\begin{tabular}{lcc} 
Kategori & Jumlah & Persentase (\%) \\
\hline Tinggi & 8 & $22,2 \%$ \\
Sedang & 19 & $52,8 \%$ \\
Rendah & 9 & $25 \%$ \\
\hline
\end{tabular}

Pada tabel 2 diatas didapatkan jumlah siswa yang terindikasi mengalami Kecemasan Matematika Tinggi (KMT) sebanyak 8 orang dengan persentase 22,2\%, jumlah siswa dengan kategori mengalami Kecemasan Matematika Sedang (KMS) sebanyak 19 orang dengan persentase 52,8\%, dan jumlah siswa dengan kategori Kecemasan Matematika Rendah (KMR) sebanyak 9 orang dengan persentase $25 \%$. Dari kategori tingkat kecemasan tersebut diambil masing-masing satu siswa yang merepresentasikan kelompoknya sebagai subjek penelitian untuk dianalisis lebih lanjut jawabannya terhadap soal materi barisan dan deret dengan 3 indikator yaitu koneksi dalam konsep dan antar konsep matematika, koneksi antara topik matematika dengan ilmu lain dan koneksi antara topic matematika dengan kehidupan sehari hari. Berikut diuraikan deskripsi masing-masing tingkat kecemasan matematika dalam menjawab soal

\section{Analisis Subjek Dengan Tingkat Kecemasan Matematika Tinggi (KMT)}

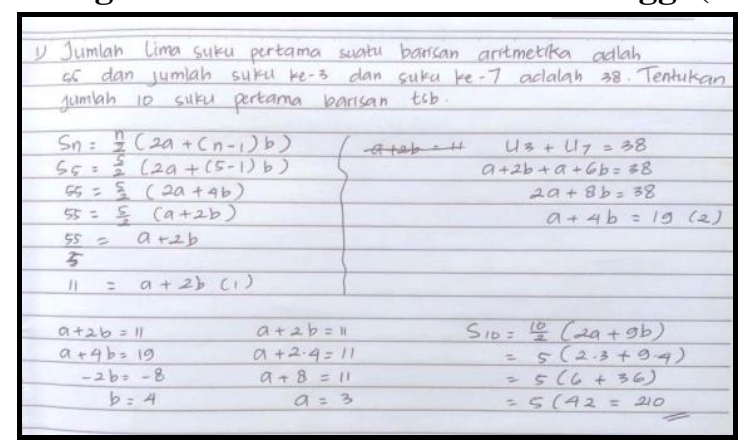

Gambar 1. Jawaban subjek KMT untuk soal no 1

Jawaban subjek tingkat kecemasan matematika tinggi (KMT)pada gambar 1 dengan indikator mengukur kemampuan koneksi dalam topik dan antar topik matematika, subjek mampu menggunakan simbol-simbol yang sering digunakan dalam materi barisan dan deret yaitu suku pertama a, beda $b$ dan rumus jumlah suku pertama yaitu $S_{n}$.Subjek dapat menguraikan konsep jumlah suku pertama barisan aritmatika dan jumlah suku ke-3 dan ke-7 dengan nilai yang diketahui pada soal dengan benar sehingga terbentuk sistem persamaan linear 
dua variabel.Subjek juga dapat mencari solusi dari sistem pertidaksamaan linear tersebut dengan menggunakan metode eliminasi meskipun pada langkah penyelesaiannya tidak begitu terstruktur.Subjek telah memiliki kemampuan koneksi matematis dalam topikmatematika yaitu konsep yang ada pada materi barisan itu sendiri. Subjek juga telah memiliki kemampuan koneksi matematis antartopik dalam matematika sehingga subjek dapat menghubungkan konsep barisan dan deret dengan konsep sistem persamaan linear dua variable yang telah dipelajari sebelumnya.

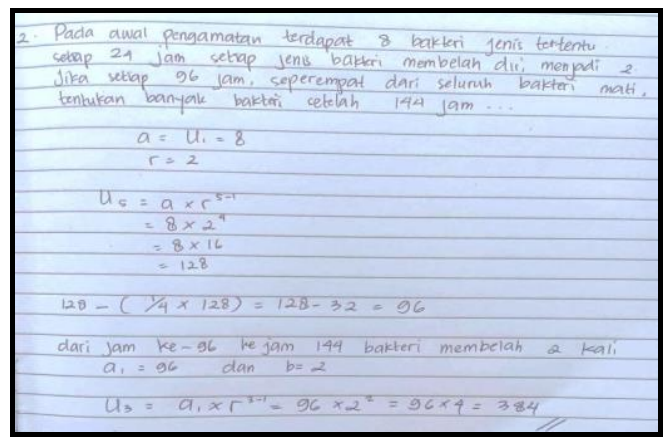

Gambar 2. Jawaban subjek KMT untuk soal no 2

Penyelesaian subjek tingkat kecemasan matematika tinggi (KMT) pada soal nomor 2 yang indikatornya mengukur kemampuan koneksi antar topik matematika dengan ilmu lain terlihat bahwa subjek telah dapat menghubungkan masalah dalam ilmu biologi dengan konsep barisan pada matematika. Subjek menuliskan jumlah awal dari bakteri dengan symbol a yang sering digunakan sebagai lambang suku pertama dari barisan. Subjek juga sudah tepat dengan memilih menggunakan konsep barisan geometri untuk menghitung perkembangbiakan bakteri yang diminta soal. Subjek dapat membedakan kapan menggunakan rasio perkembangan bakteri yaitu $r=2$ sesuai dengan keterangan pada soal, serta pada saat kapan jumlah bakteri tersebut berkurang sehingga subjek dapat memberikan jawaban yang diinginkan soal. Meskipun demikian terdapat sedikit kekeliruan saat subjek menuliskan rasio dengan $b=2$, penulis menganggap ini sebagai kesalahan yang disebabkan kurang hati hati ketika menuliskan jawaban. Pada penulisan selanjutnya subjek telah menuliskannya dengan $\mathrm{r}$ secara tepat. Berdasarkan jawaban tersebut maka subjek sudah memiliki kemampuan koneksi antara topik matematika dengan ilmu lain.

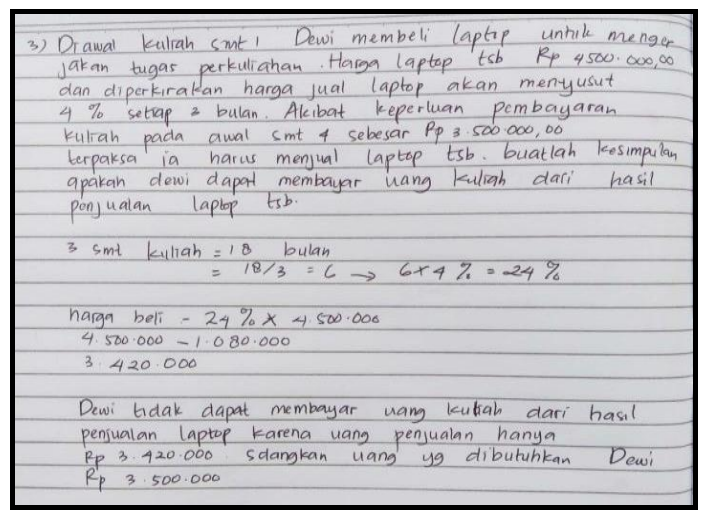

Gambar 3. Jawaban Subjek KMT untuk soal no 3

Berdasarkan jawaban subjek kecemasan matematika tinggi (KMT) untuk soal nomor 3 dimana indikatornya mengukur kemampuan koneksi antara topik matematika dengan kehidupan sehari-hari dapat terlihat bahwa pada awalnya subjek sudah bisa menentukan lamanya laptop tersebut dipakai dengan menghitung banyak semester yang telah ditempuh.Selain itu subjek 
juga telah mampu menentukan berapa kali laptop tersebut telah mengalami penyusutan yaitu sebanyak 6 kali. Namun dalam menghitung harga laptop setelah penyusutan sebanyak 6 kali, subjek melakukan kesalahan yaitu dengan mengalikan persentase penyusutan sebesar $4 \%$ dengan 6 sehingga persentase penyusutan menjadi 24\%. Kesalahan selanjutnya adalah subjek menghitung harga jual laptop setelah penyusutan yaitu harga beli dikurangi $24 \%$ dari harga beli awal. Seharusnya pengurangan dilakukan sebanyak 6 kali dengan persentase penyusutan $4 \%$ dari harga awal yang berbeda beda sesuai harga setelah dikurangi penyusutan. Jadi untuk soal ini subjek belum dapat membuat koneksi matematis antara topic pada konsep barisandengan penyusutan dengan masalah sehari hari.

Hasil analisis ketiga jawaban subjek dengan tingkat kecemasan matematika tinggi (KMT) menunjukkan bahwa subjek memiliki kemampuan koneksi matematis untuk indikator koneksi dalam topic dan antar topic matematika, koneksi antar topik matematika dengan cabang ilmu lain tetapi belum mendapatkan kemampuan koneksi matematis pada indikator koneksi antara topikdalam matematika dengan kehidupan sehari-hari.

\section{Analisis Subjek Dengan Tingkat Kecemasan Matematika Sedang (KMS)}

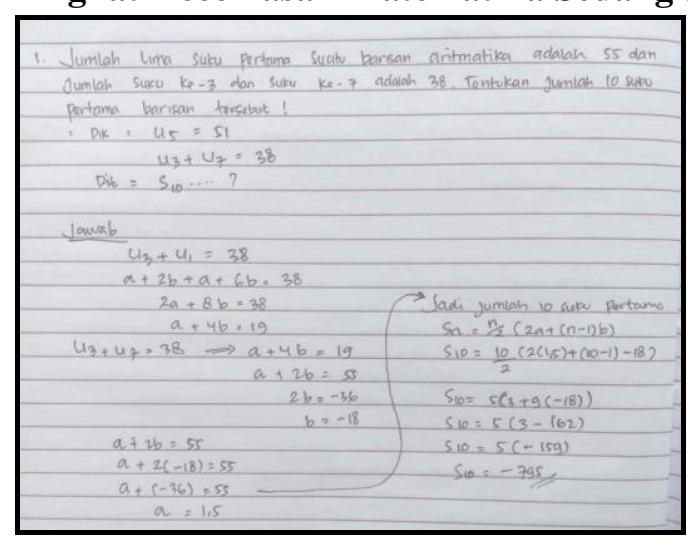

Gambar 4. Jawaban subjek KMS untuk soal no 1

Jawaban subjek dengan kategori tingkat kecemasan matematika sedang (KMS) pada gambar 4 dengan indikatoryang mengukur koneksi dalam topik dan antar topik matematika, didapatkan bahwa subjek sudah dapat menuliskan sebagian unsur unsur yang ada pada soal menjadi model matematika pada materi barisan dan deret namun subjek salah dalam membuat model matematika untuk jumlah lima suku pertama barisan aritmatika. Hal ini juga mengindikasikan bahwa subjek belum memiliki kemampuan koneksi matematis dalam topik matematika yaitu pada topik jumlah $\mathrm{n}$ suku pertama barisan aritmatika. Walaupun salah dalam menuliskan smodel matematika dari topik jumlah $\mathrm{n}$ suku pertama, subjek sebenarnya telah memiliki kemampuan koneksi antar topik dalam matematika yang terlihat dari cara subjek menggunakan metode eliminasi dari model matematika yang membentuk sistem persamaan linear dua variable. Namun karena kesalahan dalam membuat model matematika untuk jumlah lima suku pertama barisan aritmatika, maka subjek tidak bisa menjawab soal dengan tepat. 


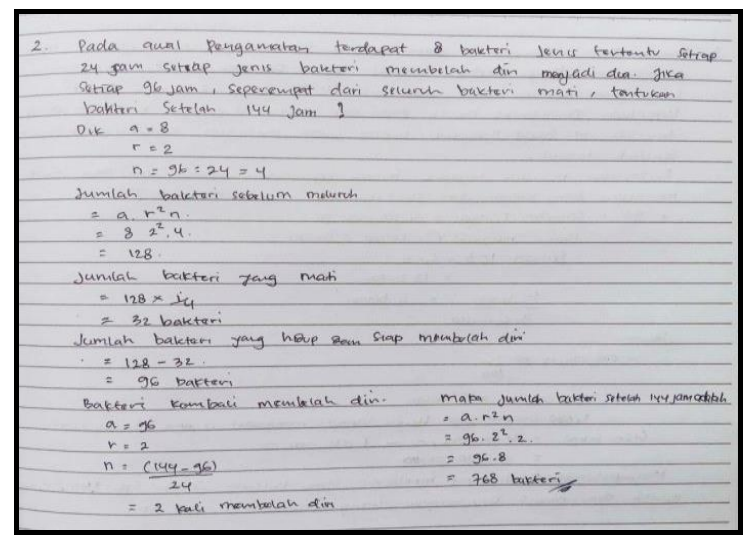

Gambar 5. Jawaban subjek KMS untuk soal no 2

Uraian jawaban subjek dengan kategori tingkat kecemasan matematika sedang (KMS) pada soal no 2 untuk yang indikatornya mengukur koneksi antar topik matematika dengan ilmu lain didapatkan bahwa pada awalnya subjek telah mampu menuliskan kembali soal tersebut dalam model matematika sesuai konsep materi barisan dan deret. Subjek dapat menuliskan jumlah awal bakteri sebagai suku pertama barisan dengan lambang a, subjek juga menuliskan pertumbuhan bakteri yang membelah diri menjadi dua bagian sebagai rasio dengan lambang $r$, serta menuliskan lamanya jam pembelahan dengan banyaknya suku dengan lambang $\mathrm{n}$. dalam menyelesaikan soal tersebut siswa salah dalam menggunakan rumus pertumbuhan bakteri, Dimana siswa menuliskan jumlah bakteri sebelum meluruh pada 96 jam pertama $=a \cdot r^{2} \cdot n$ yang seharusnya adalah a. $\mathrm{r}^{\mathrm{n}}$ walaupun secara kebetulan hasil yang didapatkan sama. Dalam menghitung jumlah bakteri setelah 96 jam pertama subjek dapat menjawab dengan benar. Kesalahan subjek dalam menghitung pertumbuhan bakteri antara 96 jam pertama sampai 144 jam yang sama juga menggunakan rumus yang salah sehingga subjek tidak dapat memenuhi permintaan soal untuk jumlah bakteri setelah 144 jam pertama. Walaupun keliru dalam menggunakan rumus, dalam hal ini subjek sudah mampu membuat koneksi matematis antara topik dalam matematika dengan ilmu lain.

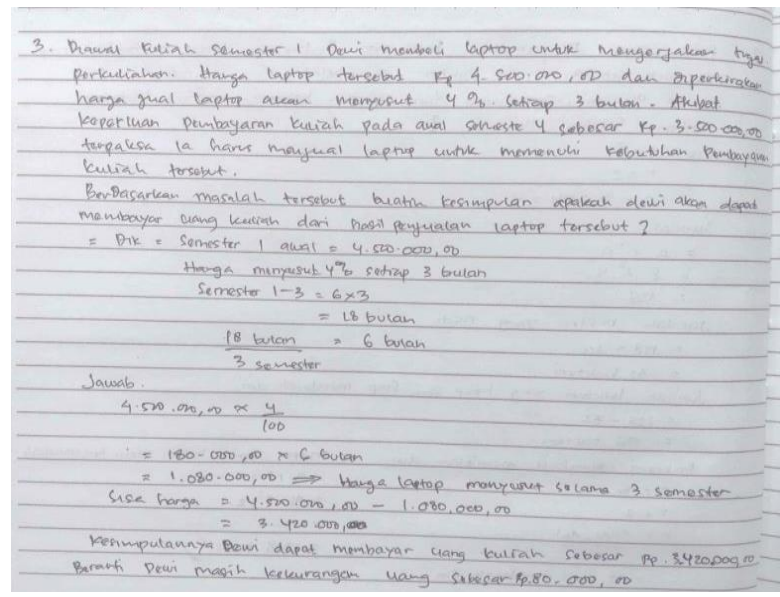

Gambar 6. Jawaban subjek KMS untuk soal no 3

Jawaban subjek tingkat kecemasan matematika sedang (KMS) untuk soal nomor 3 dengan indikator yang mengukur kemampuan koneksi antar konsep matematika dengan kehidupan sehari hari didapatkan bahwa subjek sudah menuliskan kembali unsur unsur yang diketahui pada soal. Subjek juga menghitung dengan benar lamanya pemakaian laptop tersebut yaitu menghitung banyaknya bulan $=3$ semester x 6 bulan sehingga didapatkan 18 bulan 
pemakaian, namun subjek kurang tepat dalam menuliskan banyaknya penyusutan yang terjadi dengan cara 18 bulan: 3 semester yang seharusnya 18 bulan: 3 bulan sehingga didapatkan 6 kali penyusutan. Pada penghitungan harga jual setelah mengalami 6 kali penyusutan subjek juga salah menggunakan konsep yaitu menghitung penyusutan 6 kali secara sekaligus berdasarkan harga beli awal laptop tersebut, padahal penyusutan terjadi setiap 3 bulan sekali. Selain itu subjek juga menghitung harga setelah penyusutan dengan cara harga awal $-6 \mathrm{x}$ penyusutan, seharusnya penyusutan selanjutnya dihitung berdasarkan harga terbaru setelah dikurangi penyusutan. Dalam hal ini subjek belum memiliki kemampuan koneksi antara topik matematika dengan kehidupan sehari-hari.

Hasil analisis ketiga jawaban subjek dengan tingkat kecemasan matematikasedang (KMS) menunjukkan bahwa subjek memiliki kemampuan koneksi matematis untuk indikator yang mengukur koneksi antara topik matematika namun belum memiliki kemampuan koneksi matematis untuk koneksi dalam topic matematika (barisan dan deret aritmatika). Selain itu subjek juga belum memiliki kemampuan koneksi antara topik matematika dan ilmu lain serta koneksi antara topik matematika dengan kehidupan sehari hari.

\section{Analisis Subjek Dengan Tingkat Kecemasan Matematika Rendah (KMR)}

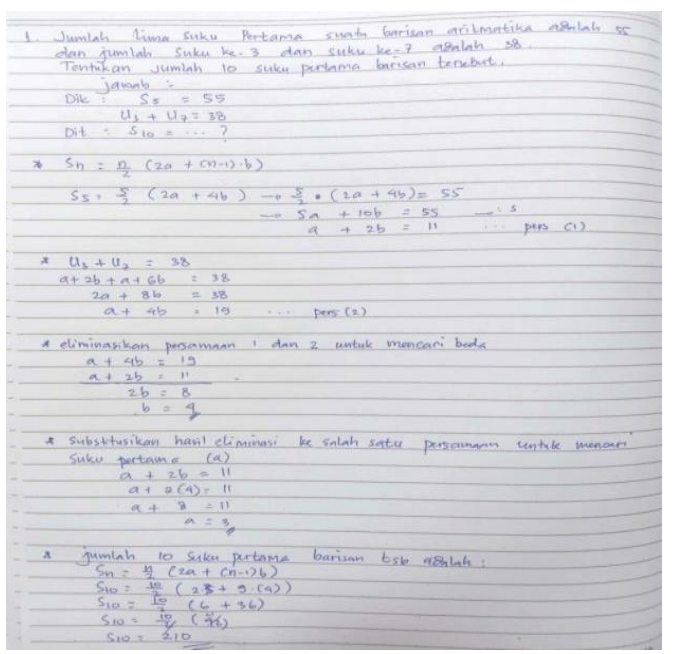

Gambar no 7. Jawaban subjek KMR untuk soal no 1

Jawaban subjek dengan tingkat kecemasan matematika rendah (KMR) untuk soal nomor 1 yaitu soal dengan indikator yang mengukur kemampuan koneksi dalam topik dan antar antar matematika, subjekdapat menuliskan unsur unsur yang diketahui pada soal dengan menggunakan simbol-simbol pada materi barisan dan deret dengan tepat. Selain itu dengan unsur yang diketahui pada soal subjek dapat menguraikannya sehingga dapat membentuk sistem persamaan linear dua variable.Subjek menguraikan rumus jumlah lima suku pertama barisan aritmatika dan jumlah suku ke-3 dan ke-7 dengan jumlah yang diketahui. Setelah terbentuk sistem persamaan linear dua variable subjek juga mampu untuk mencari penyelesaiannya dengan menggunakan metode eliminasi yang telah dipelajari pada topik yang lain pada materi sebelumnya, sehingga subjek mampu menyelesaikan soal tersebut dengan jawaban yang tepat.

Dari jawaban subjek tersebut mengindikasikan bahwa subjek telah memiliki kemampuan koneksi matematis pada indikator koneksi dalam topik matematika yaitu topik jumlah $\mathrm{n}$ suku pertama barisan aritmatika.Subjek juga telah memiliki kemampuan koneksi matematis pada 
indikator koneksi antar topik matematika dimana subjek telah mampu menghubungkan konsep barisan dengan konsep sistem persamaan linear dua variabel.

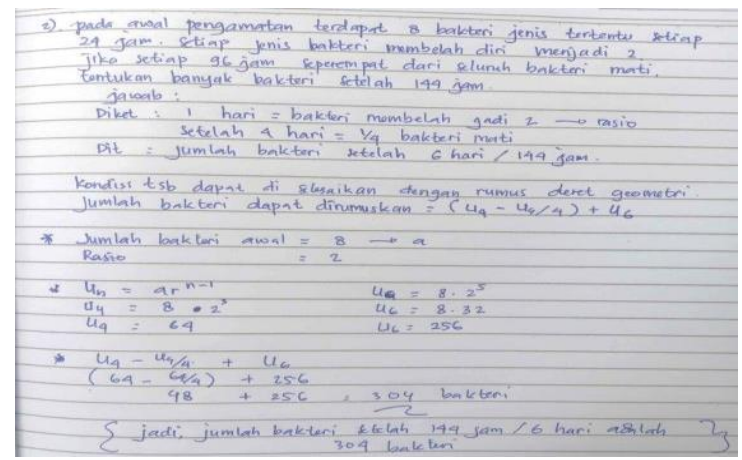

Gambar 8. Jawaban subjek KMR untuk soal no 2

Jawaban subjek tingkat kecemasan matematika rendah (KMR) pada soal no 2 dengan indikator yang mengukur kemampuan koneksi antara topik matematika dengan ilmu lain didapatkan bahwa subjek telah menghubungkan masalah pada soal dengan konsep barisan. Subjek telah menentukan jumlah awal dari bakteri dengan suku pertama dari barisan, pembelahan bakteri menjadi dua kali lipat diartikan sebagai rasio. Namun dalam menghitung jumlah bakteri setelah 96 jam pertama yang berarti 4 × 24 jam seharusnya = jumlah awal bakteri dikali rasio dipangkatkan dengan $4=a \cdot r^{4}$, namun subjek memangkatkan rasio dengan tiga.Dari jawaban subjek tersebut juga tidak terstruktur dengan baik, sehingga terlihat subjek belum mampu mengkomunikasikan idenya dengan baik. Dengan hal ini berarti subjek belum memiliki kemampuan koneksi antara topik matematika dengan ilmu lain.

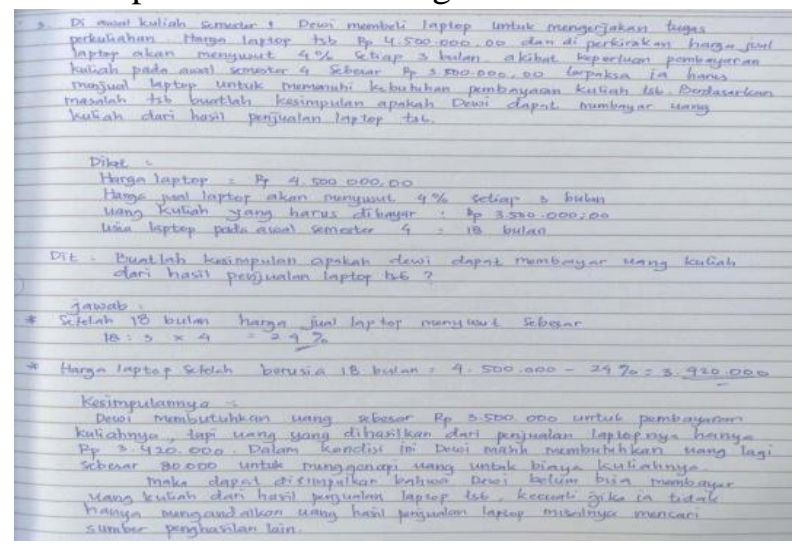

Gambar 9. Jawaban Subjek TKR untuk soal no 3

Jawaban siswa untuk soal nomor 3 yaitu soal dengan indikator yang mengukur kemampuan koneksi antara topik matematika dengan kehidupan sehari hari, subjek menuliskan kembali apa yang diketahui di soal. Subjek juga sudah benar dalam menentukan lama pemakaian laptop selama 3 semester yaitu 18 bulan.Pada saat menghitung banyaknya penyusutan subjek melakukan kesalahan dengan mengalikan persentase penyusutan dengan angka 3 (yang kemungkinan maksudnya adalah 6) sehingga menghasilkan 24\%. Kesalahan lainnya yang juga terjadi seperti pada subjek KMT dan KMS yaitu menghitung harga jual laptop setelah penyusutan selama 18 bulan dengan cara mengurangi harga awal pembelian laptop dengan total penyusutan yang dihitung dengan besar yang sama selama 6 kali penyusutan. Seharusnya besarnya penyusutan setiap 3 bulan berikutnya dihitung $4 \%$ dari harga beli setelah 
dikurangi penyusutan sebelumnya. Dalam hal ini subjek KMR belum memiliki kemampuan koneksi antara topik matematika dengan kehidupan sehari hari.

Hasil analisis ketiga jawaban subjek dengan tingkat kecemasan matematikarendah (KMR) menunjukkan bahwa subjek memiliki kemampuan koneksi matematis pada indikator yang mengukur koneksi dalam topik dan antar topik matematika, namun subjek belum memiliki kemampuan koneksi matematis antara topik matematika dengan ilmu lain serta belum memiliki kemampuan koneksi matematis antara topik matematika dengan kehidupan seharihari.

Hasil analisis jawaban subjek dari masing masing kategori yaitu KMT, KMS dan KMR didapatkan bahwa hampir semua subjek telah memiliki kemampuan koneksi matematis pada indikator koneksi dalam topik dan antar topik matematika. Namun untuk kemampuan koneksi matematis pada indikator koneksi antara topik matematika dengan ilmu lain dalam hal ini biologi dimiliki oleh siswa dengan kategori tingkat kecemasan matematika tinggi (KMT). Untuk kemampuan koneksi antara topik matematika dengan kehidupan sehari hari ternyata semua subjek belum memilikinya. Uraian diatas didapatkan anomali dimana subjek dengan KMT justru cenderung memiliki kemampuan koneksi matematika lebih banyak daripada subjek dengan kategori KMS dan KMR. Hal ini tidak sesuai dengan hasil penelitian Anita (2014) yang menyatakan bahwa masing-masing kriteria tingkat kecemasan matematika memberikan hubungan yang negatif terhadap kemampuan koneksi matematis, dimana semakin tinggi tingkat kecemasan matematika maka terjadi penurunan skor kemampuan koneksi matematis siswa. Hasil pada penelitian ini tidak sesuai dengan penelitian Kurniawati dan Siswono (Fani \& Effendi, 2021)dimana dinyatakan persamaan garis regresi menunjukkan adanya hubungan negatif antara tingkat kecemasan matematika dengan kemampuan koneksi matematis.

Begitu pula dengan hasil penelitian Puteh\&Khalin (2016) yang menyatakan adanya hubungan negative antara kecemasan matematika dan prestasi matematika siswa, dimana dengan kecemasan matematika yang tinggi akan menunjukkan kinerja matematika yang buruk dan sebaliknya. Selain itu, hasil peneitian Fista (2019) yang menyatakan bahwa siswa dengan tingkat kecemasan matematika rendah dan sedang justru regresinya bernilai positif. Hal ini didukung juga dengan pernyataan Leonard (Sistyaningtyas 2013)menyatakan kecemasan matematika juga dapat memberi dampak positif jika kecemasan muncul pada tingkat yang ringan hingga sedang. Pada tingkat kecemasan rendah dan sedang ini justru bisa memberikan kekuatan untuk melakukan sesuatu seperti membantu individu membangun pertahanan dirinya agar kecemasan yang dirasakan dapat dikurangi sedikit demi sedikit.Subjek dengan kategori tingkat kecemasan matematika rendah (KMR) dapat menjawab dengan sangat terstruktur soal pada indikator koneksi matematis dalam konsep dan antar konsep matematika, namun untuk soal dengan indikator koneksi antara konsep matematika dengan ilmu lain dan pada indikator koneksi antar konsep matematika dengan kehidupan sehari hari subjek mengalami kesulitan.

Hal tersebut bisa saja terjadi karena faktor-faktor yang mempengaruhi hasil belajar tidak hanya factor kecemasan namun juga pengaruh yang bersumber dari faktor kondisi individu siswa, meliputi kondisi psikologi berupa bakat, minat, kecerdasan, motivasi, kemampuan kognitif serta kondisi fisiologis berupa kondisi fisik dan kondisi panca indera (Purwanto, 2010). Jadi faktor kecemasan matematika bukan satu satunya faktor yang mempengaruhi hasil belajar siswa termasuk salah satunya pada kemampuan koneksi matematis ini. 


\section{SIMPULAN DAN SARAN}

Simpulan yang diperoleh dari hasil dan pembahasan yang telah diuraikan adalah semua subjek pada kategori tingkat kecemasan matematika belum memiliki semua indikator kemampuan koneksi matematis secara keseluruhan. Siswa yang mengalami kecemasan matematika tinggi (KMT) mampu membuat koneksi dalam topik dan antar topik matematika, juga koneksi antara topik matematika dengan ilmu lain. Siswa dengan tingkat kecemasan matematika sedang (KMS) hanya mampu membuat koneksi antar topik matematika dan ilmu lain. Siswa yang mengalami kecemasan matematika rendah (KMR) hanya mampu membuat koneksi dalam topic dan anatar topik matematika. Sehingga KMT secara umum kemampuan koneksi matematisnya cenderung lebih banyak dibandingkan dengan KMS dan KMR. Belum ada subjek yang mampu mengoneksikan dengan baik konsep matematika pada barisan dan deret dengan kehidupan sehari hari.

Penulis memberikan saran perlunya dilakukan penelitian lebih lanjut mengenai kecemasan matematika dan kemampuan koneksi matematis pada siswa sehingga diperoleh hubungan yang lebih spesifik.Hal ini dapat menjadi bahan pertimbangan guru dalam menentukan perencanaan pembelajaran untuk mencapai hasil belajar yang salah satunya kemampuan koneksi matematis yang lebih baik.

\section{DAFTAR PUSTAKA}

Andrian, D. (2017). Mengelola Kecemasan Siswa dalam Pembelajaran Matematika. Semnastikaunimed, 9(4), 440-449.

Anita, I. W. (2014). Pengaruh Kecemasan Matematika (Mathematics Anxiety) Terhadap Kemampuan Koneksi Matematis Siswa SMP. Infinity Journal, 3(1), 125. https://doi.org/10.22460/infinity.v3i1.43

Ashcraft, M. H. (2002). Math Anxiety: Personal, Educational, and Cognitive Consequences. Current Directions in Psychological Science, 11(5), 181-185. https://doi.org/10.1111/1467-8721.00196

Brian, K. 2012. Maths anxiety: the numbers are mounting. Diakses dari https://www.theguardian.com/education/2012/apr/30/maths-anxiety-school-support.

Cooke, A., Cavanagh, R., Hurst, C., \& Sparrow, L. (2011). Situational Effects Of Mathematics Anxiety In Pre-service Teacher Education. Paper Presented at the AARE Annual Confrence, 1-14.

Das, R., \& Das, G. C. (2013). Math Anxiety: The Poor Problem Solving Factor in School Mathematics. International Journal of Scientific and Research Publications, 3(4), 1-5.

Fani, A. A. D., \& Effendi, K. N. S. (2021). Kemampuan Koneksi Matematis Siswa Ditinjau dari Kecemasan Belajar pada Siswa SMP pada Materi Lingkaran. JPMI (Jurnal Pembelajaran Matematika Inovatif), 4(1), 137-148. https://doi.org/10.22460/jpmi.v4i1.137-148

Istikomah, E., \& Wahyuni, A. (2018). Student's Mathematics Anxiety on The Use of Technology in Mathematics Learning. JRAMathEdu (Journal of Research and Advances in Mathematics Education), 3(2), 69. https://doi.org/10.23917/jramathedu.v3i2.6364

Moelong, L. J. (2017). Metodologi Penelitian Kualitatif. Bandung: Remaja Rosdakarya.

Noer, S., H. (2017). Strategi Pembelajaran Matematika. Yogyakarta: Matematika.

Nawangsari, N. A. F. (2001). Pengaruh self-efficacy dan expectancy-value terhadap kecemasan menghadapi pelajaran matematika. Jurnal Psikologi Pendidikan: Insan media psikologi, $3,2,2001,75-88$.

NCTM (2000). Principles dan Standards for School Mathematics.

Puteh, M., \&Khlain, S. Z. (2016). Mathematics Anxiety and Its Relationship with the Achievement of Secondary Students in Malaysia. International Journal of Social Science and Humanity, 6(2), 119-122. https://doi.org/10.7763/ijssh.2016.v6.630

Purwanto, Ngalim. (2010). Psikologi Pendidikan. Bandung: Rosdakarya 
Putri dan Abadi. (2014). Keefektifan Pembelajaran Matematika dengan Pendekatan CTL dan Problem Posing Ditinjau dari Ketercapaian SK/KD dan kemampuan koneksi matematik. $\begin{array}{llll}\text { Pytagoras: } \quad J u r n a l & \text { Pendidikan }\end{array}$ https://doi.org/10.21831/pg.v9i1.9070

Saputra, P. R. (2014). Kecemasan Matematika dan Cara Menguranginya ( Mathematic Anxiety and How To Reduce It ). Journal of Chemical Information and Modeling, 3(2), 16891699. https://jurnalmahasiswa.unesa.ac.id

Sistyaningtyas, F. (2013). Hubungan Antara Tingkat Kecemasan Dengan Prestasi Belajar Matematika Siswa Kelas XI IPA di SMA Negeri 1 Kayen Pati (Universitas Muhammdiyah Surakarta). http://eprints.ums.ac.id/id/eprint/22565

Sugiyono. 2019. Metode Penelitian Pendidikan Kuantitatif, Kualitatif, kombinasi Dan R\&D. Bandung: Alfabeta.

Zakaria, E., \& Nordin, N. M. (2008). The Effects of Mathematics Anxiety on Matriculation Students as Related to Motivation and Achievement. Eurasia Journal of Mathematics, Science and Technology Education, 4(1), 27-30. https://doi.org/10.12973/ejmste/75303 